\title{
Philosophy according to Giles of Rome, De partibus philosophiae essentialibus
}

\author{
MIKOLAJ OLSZEWSKI \\ Instytut Filozofii i Socjologii PAN
}

Giles of Rome analyzed the question of the division and definition of philosophy three times at the beginning of his philosophical career. He devoted to this subject the prologues of two of his Aristotle commentaries, Commentary on the Physics and Commentary on the Sophistical Refutations. ${ }^{1} \mathrm{He}$ then devoted a work exclusively to this subject, De partibus philosophiae essentialibus (De partibus [DPPE]). ${ }^{2}$ Because of its clear, systematic approach, this text will be the main object of my analysis. I shall, however, discuss material from the two prologues that demonstrates either the evolution of Giles's thought from the two prologues to De partibus or the changes, corrections, or additions he introduced into the theory of science and philosophy formulated in De partibus.

As De partibus philosophiae essentialibus is not a well known text, I will begin with a detailed account of its contents. ${ }^{3}$ Giles's treatise is typical of its

1. Aegidius Romanus, Commentaria in octo libros Physicorum Aristotelis, (Venetiis, 1502); In Aristotelis De sophisticis elenchis commentum, (Venetiis, 1496-1497). The Prologue and I Book of Giles's Commentary on the Physics dates to 1274; the Commentary on the Sophistical Refutations dates to 1275 . See S. Donati, Studi per una cronologia delle opere di Egidio Romano, "Documenti e studi sulla tradizione filosofica medievale" (1990/1), pp. 1-111, pp. 42-48 (esp. n. 106).

2. I provide an edition of De partibus philosophiae essentialibus in the appendix. De partibus belongs to the early period of Giles's carrier. However, this dating is based on weak foundations, mostly relying on the formal and conceptual similarities between De partibus philosophiae essentialibus and De differentia rhetoricae, ethicae et politicae. See the ed. and intro. by G. Bruni, "The New Scholasticism" VI (1932), pp. 1-18. For the dating of Giles's letter (ca. 1278), see p. 4. These associations are provoked by the old printed editions, whose editors usually joined both Giles's works in their publications. Indeed, we have only one sure testimony enabling us to determine the terminus post quem of De partibus philosophiae essentialibus. It is reference made by Giles to his own In Sophisticis elenchis dated 1275. It is possible that $D e$ partibus philosophiae essentialibus was written soon after the Commentary on the Sophistical Refutations. The argument for dating De partibus philosophiae essentialibus to 1275 or 1276 rests on similarities between the two works. The last part of De partibus philosophiae essentialibus concerning logic (187-255) is virtually identical to passages from the Commentary on the Sophistical Refutations quoted in nn. 36 and 37.

3. De partibus philosophiae essentialibus has been analyzed in the literature only twice. The first analysis was L. Baur's in the commentary to his edition of 
genre and epoch. He begins his analysis of the structure of science by formulating the most general division between kinds of beings, namely, between those that are caused by intellect and those that cause intellect. As Giles himself asserts, his analysis is based on Book II of Aristotle's Physics. ${ }^{4}$ Giles notices that the Stagirite distinguishes two other causes: chance and spontaneity. But these play no role in rest of his text (DPPE 4-10).

Giles formulates his fundamental division of the sciences on the basis of this distinction between beings that are caused by intellect and those that cause intellect (DPPE 11-15). His reasoning implies that the divisions among sciences reproduce the distinctions among beings. According to this principle, each science can be distinguished from the others by means of its proper object, which is different from the proper objects of other sciences. This general rule for constructing a system of distinct sciences occurs also in Giles's Commentary on the Physics. In the first dubium of the Prologue, he notes that science does not draw its specification from that in which it is but from that about which it is. ${ }^{5}$ This assumption has its ultimate source in Aristotle and is commonly acknowledged by medieval philosophers as an important principle for constructing a system of sciences. ${ }^{6}$

Gundissalinus's De divisione philosophiae ("Beiträge zur Geschichte der Philosophie des Mittelalters", Bd. 4, Hf. 2-3 [Münster, 1903], see pp. 380-85). In two pages (382-83), Baur presents a brief summary of Giles's work. According to Baur, De partibus philosophiae essentialibus is worth mentioning among other medieval texts concerning the nature and division of philosophy because, unlike earlier works, it is based directly on Aristotle, not on late ancient (Boethius) and Arabic (Al-Farabi) authors. Baur concludes that Giles's treatise is relatively original, although influenced by the Aristolelian commentaries of Albert and Thomas. Moreover, it is remarkable because of its coherence and elegance. The second analysis of $D e$ partibus philosophiae essentialibus was J. Domański's in his recent book, La philosophie, théorie ou manière de vivre. Les controverses de l'Antiquité à la Renaissance, Vestigia. Pensée antique et médiévale, vol. 18 (Fribourg, Paris: Editions Universitaires de Fribourg Suisse-Editions du Cerf: 1996) pp. 55-58. Domański presents Giles's work as a culmination of the theoretical vision of philosophy and as the manifestation of the reduction of philosophy to metaphysics. I agree with this general view of De partibus philosophiae, but I want to show the historical context of Giles's treatise and provide a more detailed description of its contents.

4. Aristotle, Physics, II, 1-5, 192b-197a.

5. "Scientia enim non sortitur speciem ex eo, in quo est, sed ex eo, de quo est. Omnes enim scientiae in intellectu sunt, distinguuntur tamen et sortiuntur aliud et aliud esse specificum, quia sunt de aliis et aliis rebus" (Aegidius Romanus, Commentaria in octo libros Physicorum Aristotelis, f. 2va).

6. Aristotle, On the Soul, III, 8, 431b24-26. Among medieval interpreters I refer, above all, to Gundissalinus's De divisione philosophiae, ed. L. Baur (BGMP, 1903), see pp. 9:20-12:9; 12:10-13:19; Kilwardby's De ortu scientiarum, ed. A. G. Judy (Toronto: The British Academy-The Pontilical Institute of Mediaeval Studies 1976), see III:5; X:40; the fifth question of Aquinas's Super Boethium De Trinitate, Thomas Aquinas, Super Boethium De Trinitate, Editio Leonina t. L, (Roma-Paris, 1992), II:5, 1, 7; and the Prologue to Albert the Great's Physica, Opera omnia, t. IV, pars I, ed. P. Hossfeld (Aschendorff, 1987), liber I, tractatus I, De praelibandis ante 
Giles next specifies the sense in which the term "intellect" should be taken in the distinction he has just drawn. "Intellect" signifies the human intellect as distinguished from God's, because activities accomplished by God's intellect are simply the operations of nature. Nature is in fact an instrument or an organ of God. Consequently, if the term "intellect" included God's intellect, then what is caused by nature would be included among what is caused by intellect, and that would annihilate Giles's fundamental distinction between kinds of being (DPPE 20-40). Finally, Giles introduces the traditional medieval thesis that things created by God mediate between God and human beings. God's mind is the supreme cause of created things, and created things, in turn, cause human knowledge. To this scheme Giles adds a fourth element, namely, things made by human beings. These human products constitute the last element in this order; in making things, human beings imitate God's creation, in a certain sense, and are themselves a medium between human products and created things (DPPE 40-53). The distinction between things caused by nature or God and things caused by human beings, which is the central point of Giles's reasoning, is present also in Albert the Great's Physics. $^{7}$

After this digression Giles returns to his main subject, the system of sciences. First, he again draws his main distinction between beings that cause our intellect and those that are caused by it (DPPE 54-56). He then goes on to specify their kinds by dividing beings caused by our intellect into two groups, the intentional and the real. Intentional beings are the results of our thinking. Real beings are subdivided into material products (factibilia) and actions (agibilia) which determine whether our life is perfect, virtuous, and, consequently, happy or unhappy (DPPE 56-68). The final version of Giles's basic division of beings therefore consists of four groups: real beings, intentional beings, actions, and products (DPPE 68-74). These four kinds of being have their counterparts in the four main branches of science: speculative, rational, moral, and mechanical science (DPPE 77-82).

For most medieval thinkers, this general overview of the system of sciences is secondary to the division of sciences into the divine and the human. This antecedent division is based on the way the sciences are acquired. Divine science derives from divine inspiration whereas human science is an effect of the activity of human reason. In larger works devoted to the topic of the sciences-for example, Dominic Gundissalinus's De

scientiam, 1; pp. 1-13. These four works together with De partibus philosophiae essentialibus belong to the same Aristotelian tradition of defining the sciences and constitute four versions of the Aristotelian system of sciences. Comparing Giles's text with these works will enable us to see the novelties introduced by Giles and to understand him better in the historical context of his predecessors.

7. Albert the Great, Physica, I, I, 1, p. 1, 43-49. 
divisione philosophiae and Robert Kilwardby's De ortu scientiarum-this fundamental difference is presented as a preamble to the specification of secular sciences. (Kilwardby also includes another component in the basic division, namely, negative science, that is, magic. ${ }^{8}$ )

In this passage Giles uses the term scientia interchangeably with ars, treating them as synonyms. Before entering the main paragraph of his treatise concerning the essential parts of philosophy, Giles denies grammar the status of science because of its arbitrariness (DPPE 75-77). ${ }^{9}$ The problem of grammar or, more broadly, the science of language is analyzed more carefully in Giles's Commentary on the Sophistical Refutations. Having divided the sciences into the real and the logical, Giles attempts to determine the nature of the logical sciences. He begins with the etymology of the Latin term logicalis. Obviously, it derives from the Greek word logos, which has at least two meanings. It may mean reason (ratio) or speech (sermo). In general, we may name one and the same group of sciences either rational or about language (sermocinalis), but in its proper sense logic is only a rational science because the logician's goal is to direct reason. The direction of language is the task of grammar. Therefore language is grammar's proper object, and, thus, the direction of it is its proper goal. ${ }^{10}$

Giles, however, says nothing about his denial of grammar's scientific status. Throughout his works we see the constant tendency to separate logic from the so-called science of language or eloquence. For Giles, logic is something more noble and more scientific than the description of rules for understanding words. Giles's denying grammar scientific status can, thus, be perceived as a second step in the process of differentiating logic from the so-called science of language. The former formulates general rules; the latter-because of its conventional character-offers nothing but descriptions of the meanings of particular phrases and terms. The

8. Robert Kilwardby, De ortu scientiarum, III:5; Gundissalinus, De divisione philosophiae, pp. 3, 4-9.

9. This is quite unusual among medieval philosophers. All the classics of scholasticism acknowledge the scientific status of grammar, placing it together with logic and rhetoric in the group of sciences of language (see Kilwardby, De ortu scientiarum, XLIX:468), or together with poetics and rhetoric in the sciences of eloquence (see Gundissalinus, De divisione philosophiae, p. 3, 12-14). However, an Aristotelian argument can be formulated against this scholastic majority, namely, that Aristotle did not treat grammar as a science in any of his works.

10. "Logicalis scientia dicitur a logos. Et quia logos graece latine sermo vel ratio interpretatur, dialectica proprie loquendo non dicitur a logos, quod est sermo, sed a logos, quod est ratio. Nam si communi nomine scientiae rationales possunt dici sermocinales, et econverso, tamen, ut patet per habita, dialectica proprie est rationalis, quia est directiva intellectus et rationis, grammatica vero proprie est sermocinalis, quia dirigit sermonem et linguam" (Aegidius Romanus, In Aristotelis De sophisticis elenchis commentum, f. 2rb). 
observation that names are conventional is present also in his Commentary on the Physics. ${ }^{11}$

From the beginning of this part of his treatise, Giles adds the third term philosophia to the pair of scientia and ars. The motive behind introducing this new category is probably a response to Aristotle's statement that the main goal of philosophy is an inquiry into truth. It seems nevertheless that Giles uses these three terms synonymously. The thesis he wants to prove is that only the speculative sciences constitute essential parts of philosophy (solae speculative artes essentiales partes philosophiae esse dicuntur, DPPE 83-84). The justification of his thesis is provided by the argument that the main goal of philosophy is an inquiry into truth. This inquiry can be carried out only when it deals with the principal and per se object of our intellect. Giles takes these two notions - that philosophy aims at truth and that philosophy deals with intellect's principal and per se object - to be criteria for measuring the essentiality of sciences (DPPE 84-89). The first criterion is not satisfied by the moral and mechanical sciences, which aim not at knowing the truth but at action or the production of a concrete result (DPPE 89-96). The second criterion is not satisfied by dialectic, which is the cardinal rational science, for it does not concern real things, the principal and per se objects of intellect. Dialectic, however, meets the first criterion because it aims at truth (DPPE 96-103). Both criteria are satisfied only by the speculative sciences (DPPE 104-106). It seems to me that, for Giles, a science's being an essential part of philosophy results merely from meeting these two criteria; they constitute the essence of philosophy, and when something satisfies the essence of philosophy, it can be named as one of its essential parts. This technical sense of the term "essential" does not rule out its broader meaning, that is, "principal," "main," or "basic." Moreover, it explains why the speculative sciences and not other parts of philosophy are essential in the broader sense.

It is quite probable that the direct source of the formula essentialis pars philosophiae is to be found in Michael Scott's translation of the Metaphysics and of Averroes's commentary on it. According to Michael Scott's translation, Aristotle's text is:

modi igitur philosophiae essentiales sunt tres: mathematicus, naturalis et divinus; ${ }^{12}$

and Averroes's is:

manifestum est igitur ex hoc sermone, quod modi philosophiae speculativae sunt tres: scilicet scientia rerum mechanicarum et naturalium et

11. "Nomina sunt ad placitum" (Aegidius Romanus, Commentaria in octo libros Physicorum Aristotelis, f. 3ra). This statement has an interesting context. Giles employs it to persuade that the universally accepted usage of the name does not determine the nature or essence of the named object because we can arbitrarily produce a new definition of a name.

12. Averroes, In Metaphysicam, Apud Iunctas, f. 145L. 
divinarum, scilicet substantiarum, in quorum definitione accipitur Deus. ${ }^{13}$

This problem plays no important role in Averroes's text and receives no further analysis. As Domański has pointed out, Albert the Great also used the expression essentialis pars philosophiae in his Physics. ${ }^{14}$

The formula essentialis pars philosophiae is present in both of Giles's Aristotelian commentaries, as are other ideas from the central part of De partibus philosophiae essentialibus. In the Commentary on the Sophistical Refutations he states that logic cannot be an essential part of philosophy. ${ }^{15}$ This thesis occurs in a dubium entitled Whether logic is a necessary and essential part of philosophy. Here, Giles maintains that science properly should concern things; therefore, the classic tripartite division of the sciences depends on distinctions among things. Subsequently, Giles quotes the famous fragment from Aristotle's Metaphysics, and alludes to the Boethian conception of three modes of abstraction. He then refers to his own Commentary on the Physics remarking that he had discussed this theory at greater length there. 16

Before turning to the Commentary on the Physics, I would like to point out one more thesis that Giles advances in his Commentary on the Sophistic Refutations, namely, that dialectic does not fulfill the notion of science. ${ }^{17}$ The justification of this statement is formulated in the third dubium of the Prologue entitled Whether dialectic can be properly called a science. In this passage, Giles asserts that dialectic is a mode of knowing rather than a science because science is in the intellect and concerns things that can

13. Averroes, In Metaphysicam, VI, comm. 2, f. 146GH.

14. J. Domański, La philosophie, théorie ou manière de vivre, n. 19 to chap. II, refering to Albert the Great, Physica, I, 2, 1, p. 16, 3-4; the same expression is also used in the Prologue, I, I, 1, p. 1, 43-45. But in his De praedicabilibus Albert points out that Al-Farabi and Avicenna used a similar formula (realis pars philosophiae) in their criticism of ascribing logic the status of science (Albertus Magnus, Opera omnia, ed. A. Borgnet, [Parisiis, 1890], vol. 1). Albert's own solution is opposite, he says that logic, insofar as it tends to the truth, can be generally named science (see p. $4 a)$.

15. See Aegidius Romanus, In Aristotelis De sophisticis elenchis commentrum, f. 2rb. Giles restricts himself only to the assertion that logic is not scientia realis.

16. "Cum scientia sit proprie de rebus, partes essentiales philosophiae accipiuntur secundum divisionem rerum. Et quia res tripliciter possunt accipi, vel ut coniunctae motui et materiae secundum esse et definitonem, ut naturalis; vel sunt coniunctae secundum esse, et non secundum definitionem, ut mathematica, vel nec sunt coniunctae secundum definitionem nec secundum esse, ut scientia divina, ideo dicitur VI Methaphysicae, quod tres sunt modi essentiales philosophiae: physicus, mathematicus et divinus. Hoc autem in declarationibus, quas super primo Physicorum edidimus, plenius tractavimus" (See Aegidius Romanus, In Aristotelis De sophisticis elenchis commentum, f. 3ra).

17. "Igitur secundum hunc modum dialectica sicut deficit a ratione scientiae, sic deficit, quod non est essentialis pars philosophiae" (See Aegidius Romanus, In Aristotelis De sophisticis elenchis commentum, f. 3ra). 
properly be intellect's objects. But these objects are things external to intellect. Thus, since dialectic treats intentions that exist in the intellect, it cannot be a science in the strict sense of the word. ${ }^{18}$ This reasoning can easily be transformed into the second criterion for the essentiality of science as formulated in De partibus philosophiae essentialibus.

In his Commentary on the Physics, Giles gives less attention to this piece of his theory of science, focusing instead on other observations concerning the nature of the branches of philosophy or science. He starts his inquiry into the nature of physics and its place in the system of sciences with the distinction between practical and speculative sciences. The former have as their goal the good or some product. By contrast, the latter, including physics, aim at truth. So all the sciences that aim primarily at the good pertain only secondarily to truth; and sciences that have as their main goal knowing the truth can attain the good only accidentally. The final conclusion of Giles's argumentation is this: neither the sciences having to do with acting (operativae) nor the rational sciences can be essential parts of philosophy. ${ }^{19}$ We can see, then, that Giles's central idea remains the same throughout his works. However, its clearest and most elegent expression is in $D e$ partibus philosophiae essentialibus.

Having established his thesis, Giles proceedes to the subdivisions of the speculative sciences. He reproduces Aristotle's famous division formulated in the sixth book of the Metaphysics, which distinguishes three speculative sciences: namely, divine science or theology (that is, metaphysics in the post-ancient terminology), mathematics, and physics. ${ }^{20}$ The distinction de-

18. "Ratio autem, quia dialectica est magis modus sciendi quam scientia, ex hoc sumi potest, quia scientia est in intellectu. Et de illis proprie et principaliter est scientia, quae proprie et principaliter possunt esse obiectum intellectus. Cum ergo intellectus per se et primo intelligit ipsas res et alia a se et intelligendo ea intelligit seipsum, ut potest haberi ex III De anima commento 15, nihil, quod est in intellectu, secundum quod huiusmodi poterit principale esse obiectum intellectus. Dialectica ergo, quae est de conceptibus et intentionibus, ut sunt quid rationis, proprie scientia esse non poterit, erit tamen modus sciendi” (See Aegidius Romanus, In Aristotelis De sophisticis elenchis commentum, f. 2vb).

19. "Naturalis scientia est aliqua scientiarum speculativarum, ut dicitur VI Metaphysicae. Speculativa autem scientia differt a practica quantum ad finem, quia finis speculativae est veritas, practicae autem opus, ut declarari habet II Metaphysicae, vel ut quaedam translatio habet, practicae finis est bonum. Et in idem redit, quia omnis actio vel omnis electio et proheresis bonum aliquod considerare videtur, ut habet declarari I Ethicae . . Ex hac autem differentia, quam esse conspicimus inter scientiam speculativam et practicam, patere potest, quod licet speculativa ad philosophiam essentialiter possit pertinere, practica autem quasi per accidens ad philosophiam se habebit. Nam cum philosophia, et universaliter omnis scientia, in intellectu consistat, ad scientiam et ad philosophiam illa essentialiter pertinere poterunt, in quae fertur intellectus secundum se. Obiectum autem potentiae intellectivae est verum et per se intellectus fertur in veritatem" (Aegidius Romanus, Commentaria in octo libros Physicorum Aristotelis, f. 2ra).

20. Aristotle, Metaphysics, VI, 1, 1026a18-19. 
pends on the level of abstraction proper to each science (DPPE 104-113). Giles offers two parallel orders of abstraction, which can be used as a basis of the division of the speculative sciences. The first one is the order of abstraction characteristic of the sciences themselves. Every science abstracts from different kinds of materiality: physics abstracts from this or that sensible matter which is a part of this or that thing; mathematics abstracts from sensible matter completely, although it concerns intelligible matter; metaphysics abstracts from every kind of matter (DPPE 113-126). The second order is an order of abstraction typical for the objects of each of the sciences. Physics concerns things that are abstracted from matter neither as beings (secundum esse) nor in their definitions (secundum definitionem).21 Mathematics deals with things abstracted in their definitions only, metaphysics with things abstracted in both ways (DPPE 126-130). The tripartite division of the speculative sciences and the modes of abstraction appealed to as its ground are typical indices of Aristotelian systems of sciences. ${ }^{22}$

21. This mysterious formula finds its best intepretation in Aquinas's Super Boethium De Trinitate (see II, 5, 1, corp.). Instead of the thing abstracted as regards being (secundum esse), Aquinas puts simply immaterial thing. Instead of abstraction as regards definition (secundum definitionem) Thomas speaks about abstraction in the intellect. According to him, the thing abstracted in intellect means that in the definition of such a thing formulated in our intellect there is no matter, although it is possible that this thing has in fact matter as its part. It is exactly the case of the objects of mathematics, which can exist only as material, though they are intellected as pure structures devoid of any matter. Moreover, Aquinas presents a justification for the sufficiency of a number of the speculative sciences. He asserts, namely, that if we combined these two kinds of abstraction, in being and in intellect, we would obtain four possible species of things: abstracted in being and definition, which are treated by metaphysics; not abstracted in being nor in definition, that is the objects of physics; abstracted in definition but not abstracted in being, which concerns mathematics; and not abstracted in definition but abstracted in being. The last possibility, however, has no designates, since nothing can be in fact immaterial and known as material.

22. Besides Aquinas (see n. 21), this concept is proper also to Gundissalinus (De divisione philosophiae, pp. 14:19-15:15), Kilwardby (De ortu scientiarum, XXV:203), and Albert the Great, (Physica, I, I, 1, pp. 1, 45-60). Its ultimate source is, of course, Boethius's De Trinitate, which was repeated by all the above mentioned authors; see Boethius, De Trinitate, in: Thomas de Aquino, Super Boethium De Trinitate, p. 69, 68-79. The tripartite division of the speculative science and its principle (the theory of three modes of abstractions) is also mentioned in Giles's Commentary on the Physics: "Si rationales et operativae essentiales philosophiae partes esse non possunt, solae considerationes physicae, mathematicae et divinae ad philosophiam pertinere videntur. Ex hoc autem innotescit veritas illa, quae scribitur VI Metaphysicae, quod tres sunt modi essentiales philosophiae: videlicet naturalis, mathematicus et divinus. Horum autem sufficientia haberi potest secundum Commentatorem VI Metaphysicae. Entia enim vel circumcernunt materiam et motum secundum esse et secundum definitionem, vel sunt abstracta secundum definitionem et non secundum esse, vel utroque modo abstracta esse dicuntur. In primo gradu sunt naturalia, in secundo mathematica, in tertio divina" (Aegidius Romanus, Commentaria in octo libros Physicorum Aristotelis, f. 2ra). 
Giles ends his considerations of the nature of the speculative sciences by presenting the subdivisions of mathematics. He maintains that metaphysics and physics are not subject to further distinctions (DPPE 130-131). The integrity of metaphysics was commonly accepted by scholastic philosophers. The internal unity of physics, on the contrary, is an original concept. Unfortunately, Giles does not offer any proof of it.

Moreover, in his Commentary on the Physics, ${ }^{23}$ Giles proposes a fully developed subdivision of physics. He asserts that the proper object of physics is moving body, which is subject to further divisions. Moving body as such (simpliciter) is treated in physics, and its specific kinds are described in several of Aristotle's works. The full scheme of these subdivisions or branches of natural science and the corresponding titles of the Stagirite's works can be presented diagrammatically:

moving body

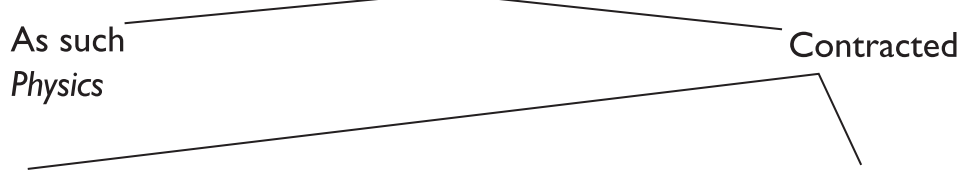

By local motion

By motion toward form

On the Heavens and the Universe

In general

On Generation and Corruption

In particular

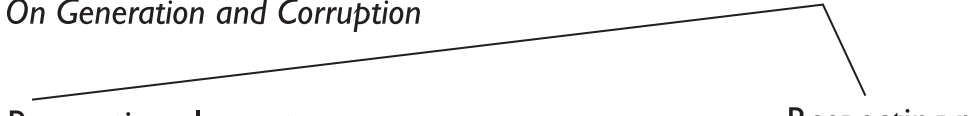

Respecting elements

Respecting mixtures

Meteorology

Inanimates

Animates

On the minerals

In general

In particular

On the Soul

About vegetable soul

About sensible soul

On plants

On animals

23. See, Aegidius Romanus, Commentaria in octo libros Physicorum Aristotelis, f. 2rb. 
Analogous constructions can be found in Gundissalinus's De divisione philosophiae, ${ }^{24}$ Kilwardby's De ortu scientiarum, ${ }^{25}$ and Albert's Physica. ${ }^{26}$ They all propose fully developed and complicated subdivisions of physics based on the variety of moving bodies and in full agreement with the structure of Aristotle's work. The most striking advantage of Giles's subdivision of physics is the perfect logical form of his Porphyrian tree, a feature missing from earlier accounts. Although all the philosophers mentioned above begin from physics as dealing with moving body as such, they differ in virtue of their subdivisions, especially in the case of the sciences dealing with animate things.

What remains a mystery is Giles's motive for changing his mind in De partibus philosophiae essentialibus and giving a negative answer to the question whether physics is subject to subdivision. He discusses a similar question in the last dubium of the Prologue of his Commentary on the Physics, where he states that physics and natural science (understood as a sum of the special branches of physics) do not have the same object because physics analyzes moving body universally whereas natural science analyzes moving body in each of the particular aspects in which it can be considered. ${ }^{27} \mathrm{~A}$ difference in the objects of sciences is a sufficient foundation for distinguishing the sciences.

There is one more element carefully analyzed by Giles in his Commentary on the Physics that is only marked in De partibus philosophiae essentialibus, namely, the relations between physics and metaphysics. These relations are the subjects of the two first dubia, Whether physics precedes metaphysics and Whether physics is subordinate to metaphysics. Giles give a negative answer to the first question. His argument is based on the ontological priority of the object of metaphysics (abstracta) over the object of physics (sensibilia). ${ }^{28}$ At the same time, physics is independent from metaphysics because the principles of physics derive from sensible things that are the direct source of the

24. See, Gundissalinus, De divisione philosophiae, pp. 20:11-23:15.

25. See, Robert Kilwardby, De ortu scientiarum, X:41-58.

26. See, Albert the Great, Physica, I, I, 4, pp. 6:39-7:64.

27. "Ulterius forte dubitaret aliquis, utrum sit idem subiectum in tota philosophia naturali et in hoc libro. Et videtur, quod sic, quia in hoc libro subiectum est corpus mobile simpliciter non contractum ad hoc vel ad illud. Sed corpus mobile est subiectum simpliciter in tota philosophia naturali, ergo etc.

Ad hoc autem dici oportet, quod aequivoactur in eo, quod simpliciter. In tota enim philosophia naturali subiectum est corpus mobile sumptum simpliciter, id est, sumptum secundum omnem acceptionem, ad naturalem enim pertinet et considerare de corpore mobili secundum omnem modum et secundum acceptionem motus. In hoc autem libro subiectum est corpus mobile sumptum simpliciter, id est universaliter. Consideratio autem particularis de corpore mobili non pertinet ad hunc librum, pertinet tamen ad philosophiam naturalem" (Aegidius Romanus, Commentaria in octo libros Physicorum Aristotelis, f. 3vb). 2va.

28. See Aegidius Romanus, Commentaria in octo libros Physicorum Aristotelis, f. 
principles' evidentness. The principles of physics therefore cannot be reduced to any principles of metaphysics. Giles gives two examples of the subordination of one science to another. The first is the case of perspective and geometry. The object of perspective is a visible line, but perspective makes use of some principles that it cannot prove but are proved by geometry, which deals with the line as such. Geometry thus subordinates perspective. Giles employs the same structure of reasoning in De partibus philosophiae essentialibus in the presentation of the subdivision of mathematics. Giles's second example is that of medicine and physics. The proper object of medicine is the human body, which is, however, particular. Since principles of knowledge must be expressed in general statements, medicine has to accept some assertions from a higher science, that is, from physics.

This kind of definition of the object of medicine can serve as a reason for taking medicine to be a part of physics since human body is a particular kind of moving body. But medicine is not mentioned in Giles's division of physics presented above. Perhaps we can explain this incongruity by adapting Kilwardby's thesis that medicine in its essence is one of the mechanical sciences. ${ }^{29}$

Giles ends this dubium by asserting that physics is not subordinate in either of these ways by metaphysics but itself subordinates sciences dealing with the various aspects of moving bodies. ${ }^{30}$

Giles's views on the mathematical disciplines are governed by the division of its object, that is, quantity, into discrete and continuous. A discrete quantity is an object of arithmetic, while continuous quantity is an object of geometry. This is followed by the applied mathematical sciences. For instance, perspective is a science of continuous quantity applied to sight. Among the applied branches of mathematics are music, astronomy, and stereometry (the science of the measure of buildings) (DPPE 131-150).

Giles next presents the division of mechanics. First, he ennumerates several kinds of mechanical arts (craft, carpentry, spinning, weaving); he then formulates a criterion by which he establishes a hierarchy of mechanical sciences. Giles states that some mechanical sciences deal with form and others deal with matter. Those mechanical sciences that deal with form dominate and are served by those that deal with matter. For example, shipcraft subordinates carpentry, and spinning serves weaving (DPPE 151-164).

It is worth noting that Giles's division of mechanics is distant from Hugh of St. Victor's classic division. Hugh asserted that are seven mechanical sciences on analogy with the seven liberal arts: weaving, armour-making, agriculture, hunting, navigation, medicine, and theatre. ${ }^{31}$ Kilwardby ob-

29. Robert Kilwardby, De ortu scientiarum, X:57.

30. Aegidius Romanus, Commentaria in octo libros Physicorum Aristotelis, f. 2vb-3ra.

31. Hugo de Sancto Victore, Didascalicon, II:21. 
jected to Hugh's position, doubting whether is was necessary to maintain that the mechanical sciences were exactly seven, and whether Hugh's list was adequate. ${ }^{32}$ Giles does not even mention Hugh's scheme; he ennumerates among the mechanical sciences some that Hugh does not touch on, and he omits others named by Hugh. One may conclude that Kilwardby's and Giles's reflection on the mechanical sciences is marked by the tendency to liberate them from the twelfth-century theories. Giles emphasizes the internal range the of mechanical sciences, which is the result of his applying to them a measure deriving from Aristotle's distinction between form and matter.

In his discussion of the moral sciences Giles offers the typical tripartite division into ethics, economics, and politics. These three are distinguished from each other by differences in the communities or unions that they rule and whose good they determine. Ethics prescribes rule for the union and subjection of the irascible and concupiscible parts of the soul to its rational part. Economics establishes rules for the family, understood here in the broad Aristotelian sense, governed by a paterfamilias. Politics concerns the country reigned by a king (DPPE 165-186). What is striking here is that the description of ethics as a set of rules determining the rational soul's governance of the soul's other parts seems artificial and a rather mechanical extrapolation of the structure proper to politics. Politics thus becomes an archetype of moral science.

Giles ends his analysis of the system of sciences with a description of the rational sciences. He commences by repeating his remark that the proper objects of rational sciences are not actions of reason but their effects or intentions. In his Commentary on the Sophistical Refutations, Giles adds two arguments in support of this assertion. In the first, Giles asserts that dialectic is a science of reason, and reason refers to its act and to the object of its act. But reason refers to its object per se and to its act only secondarily (according to Aristotle's statement that self-knowledge depends on the knowledge of an extramental object). So intentions, which are the objects of intellect, are the objects of dialectic as well. In the second argument, he observes that these intentions, not the operations of intellect, are indeed the subject-matter of Aristotle's investigations in all his logical works. ${ }^{33}$ Giles's statement that intentions, not actions of intellect, are rational science's proper object is obviously an attack on Aquinas's commentaries on Aristotle's logical works. In both his commentaries, Thomas asserts that actions of reason are the proper object of logic. ${ }^{34}$

32. Robert Kilwardby, De ortu scientiarum, XL:372-78.

33. Aegidius Romanus, In Aristotelis De sophisticis elenchis commentum, f. 2va.

34. "[Logica] non solum rationalis est ex hoc, quod est secundum rationem, quod est omnibus artibus commune, sed ex hoc, quod est circa ipsum actum rationis, sicut circa propriam materiam" (Thomas de Aquino, Expositio libri Posteriorum, Opera omnia, t. I*, 2 [Roma-Paris, 1989], p. 3, 25-28; see also, Expositio libri Perihermeneias, Opera omnia, t. I*, 1 [Roma-Paris, 1989], p. 5, 1-17). 
There are four relevant kinds of intentions, namely, example, enthymeme, induction, and syllogism. The first two are employed by rhetoric and the last two by dialectic. Since induction and syllogism are more powerful means of arguing than example and ethymeme, dialectic subordinates rhetoric (DPPE 187-213).35 Almost identical reasoning can be found in Giles's Commentary on the Sophistical Refutations. 36

Putting aside the question of the subdivisions of rhetoric, Giles concentrates on the subdivisions of dialectic. Each part of dialectic deals with different operations of reason. There are three operations: defining, ascribing a definition to an object (that is, forming a proposition), and composing a syllogistic argument from propositions. These three are treated by Aristotle in three treatises: definition in De Interpretatione, proposition in Categories, and syllogism in the set of logical writings known in the Middle Ages as the logica nova. Giles excludes Porphyry's Isagoge and the Liber sex principiorum from the essential parts of logic and counts them rather as introductory for logic (DPPE 214-238).

Giles continues to apply this scheme to describe the branches of logic dealing with the various kinds of syllogisms. While he treats syllogism generally in Prior Analytics, Giles addresses the subject in more detail in other works. According to Giles, there are different kinds if syllogisms depending on the necessity of the syllogism's matter and on the syllogism's topical properties. The first case is described in Posterior Analytics. The second is twofold: topical properties are probable and coherent or they are not. The former possibility is treated in Topics, the latter in Sophistical Refutations (DPPE 239-255). This part of Giles's subdivision of dialectic is a simple repetition, in abbreviated form, of his theory of the branches of logic presented earlier in his Commentary on the Sophistical Refutations. ${ }^{37}$

This division of logic is deeply rooted in Albert's and Aquinas's earlier

35. That motif derives directly from Aristotle's Rhetoric, as Giles himself acknowledges. See Aristotle, Rhetoric, I, 1, 1354a.

36. "Dicere possumus, quod inter ea, quae ex parte rationis se tenent, quaedam sunt violentiora et magis efficatia, quaedam vero sunt infirmiora et magis debilia. Ut syllogismus est magis effcatior quam enthymema. Et inductio quam exemplum. Est ergo rationalis dialectica et rhetorica, aliter tamen et aliter, quia dialectica principaliter considerat, quae sunt efficatiora ad concludendum, ut sunt syllogismus et inductio. Rhetorica vero considerat debiliora, ut enthymema et exemplum. Est enim inductio efficatior exemplo, sicut syllogismus efficatior enthymemate. Rhetorica ergo non est dialectica, est tamen aliquo modo assecutiva [in cod. executiva] dialecticae, quia ea, de quibus considerat rhetorica, reducuntur et ordinantur ad ea, quae considerantur in logica sicut infirma ad fortiora" (Aegidius Romanus, In Aristotelis De sophisticis elenchis commentum, f. 3va).

37. "Sunt ergo isti tres actus intellectus: primus est simpliciter cognoscere, secundus componere et dividere, tertius est discurrere et inferre. Secundum hos tres actus tria format. Nam intelligendo simplicia format simplicem conceptum et definitionem; intelligendo composita format enuntiationem; discurrendo format syllogismum. Ideo secundum hos tres actus rationis consuevit communiter dividi logica in tres partes: videlicet quantum ad intellectum simplicem in Praedicamenta; 
commentaries on Aristotle's Organon. In his De praedicabilibus, Albert begins with the assertion that logic deals with everything by means of which we can obtain knowledge of something that was previously unknown. The most excellent instrument for acquiring knowledge is the syllogism; therefore, it is the proper object of logic. ${ }^{38}$ Albert next divides logic into the science of definition and the science of judgment. ${ }^{39}$ He then continues his reflection on the parts of logic saying that the science of invention, that is, the invention of definition, is described in Aristotle's Topics, while the science of judgment is addressed in Prior and Posterior Analytics (depending on whether the correctness of the syllogism is formal or material). Moreover, Sophistical Refutations should prevent us from making mistakes in reasoning and Universalia and Categories explain the structure of the parts of syllogism. ${ }^{40}$

Giles's division of logic is even nearer to Aquinas's. Aquinas begins with the basic tripartite division of logic into sciences dealing with different actions of reason, namely, definition, the forming of propositions, and reasoning. There is, however, a difference between Aquinas and Giles with regard to the linking of these actions with Aristotle's works. Aquinas says that definition is treated in Categories and judgment in De Interpretatione. ${ }^{41}$

According to Aquinas, the science of reasoning is divided into three parts. The science of resolution deals with the syllogism, the certainty of which depends on its form or on its matter. The former possibility is treated in Prior Analytics, the latter in Posterior Analytics. Next is the science of invention, which pertains to statements lacking certainty. These statements are subdivided into opinions (which are expressed in probable syllogisms

in Perihermeneias quantum ad intellectum compsitum; et in libros artis novae quantum ad illum actum intelligendi, qui est discurrere et inferre. Hoc autem etsi bene dictum est, videtur tamen, si per se loqui volumus, quod magis accipienda sit divisio dialecticae secundum conceptus et intentiones, quae formantur ex his actibus, ut dicamus, quod in libro Praedicamentorum determinatur de simplicibus conceptibus, ut de quidditatibus et conceptibus decem generum. In libro autem Perihermeneias determinatur de enuntiatione, quae formatur ex intellectu componente et dividente: componente quantum ad enuntiationem affirmativam, dividentem quantum ad negativam. In libris autem artis novae determinatur de syllogismo, qui formatur ex intellectu discurrente et inferrente. Libri ergo artis novae dividi possunt secundum divisionem syllogisticam. Syllogismus enim dupliciter potest accipi, simpliciter et contractus. Si sumatur simpliciter, sic determinatur de eo in libro Priorum. Si autem contrahatur, hoc erit dupliciter, quia vel contrahitur ex necessitate materiae, et sic est liber Posteriorum, vel ex habitudine locali. Et hoc dupliciter, quia huiusmodi habitudo vel est congrua, ubi poterit salvari forma syllogistica, et sic est liber Topicorum; vel erit forma incongrua, ubi forma syllogistica salvari non potest, et sic est liber Elenchorum" (Aegidius Romanus, In Aristotelis De sophisticis elenchis commentum, f. 2rb).

38. Albert the Great, De praedicabilibus, I, 4, p. 8a-b.

39. Albert the Great, De praedicabilibus, I, 5, p. 8b.

40. Albert the Great, De praedicabilibus, I, 7, p. 15a-b.

41. Thomas de Aquino, Expositio libri Perihermeneias, p. 5, 15-30; Expositio libri Posteriorum, p. 4, 29-46. 
and are the subject of Topics), suspicions (treated in Rhetoric), and estimations (described in Poetics). The third part of the science of reasoning has as its proper object sophistical syllogisms of the sort analyzed by Aristotle in his Sophistical Refutations. ${ }^{42}$

This part of Aquinas's subdivision of logic might seem further from Giles's account than it actually is. If one were to remove rhetoric and poetics from Aquinas's science of invention, one would obtain exactly Giles's system of the sciences of the syllogism. Giles's displacement of rhetoric and poetics is entirely reasonable and makes the structure of the division of rational sciences tighter and more elegant.

The whole of Giles's system of the sciences, then, can be presented diagramatically:

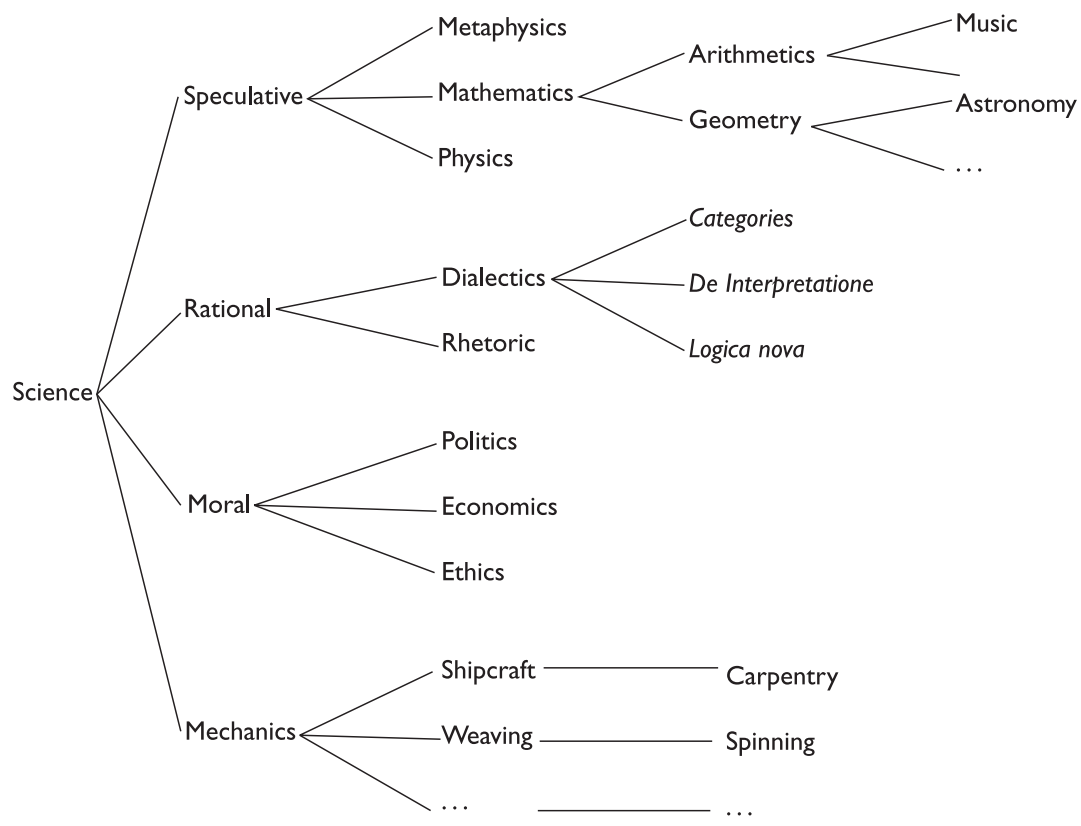

As we can now see, the main points of Giles's reflections on science and philosophy are almost identical in his three works. Material gathered in his commentaries is used in the systematic presentation in De partibus philosophiae essentialibus. Therefore, we might view his theory as nothing other than a reformulation of the Aristotelian conception of science and philosophy. But a more interesting perspective on Giles's text and a deeper insight into the very essence of his position become available when Giles's account is placed in the broader context of the great discussions of the epoch.

Having presented the contents of De partibus philosophiae essentialibus, I

42. Thomas de Aquino, Expositio libri Posteriorum, pp. 5, 50; 7, 127. 
now turn to Giles's thesis that only speculative sciences constitute the essential parts of philosophy. In order to understand the proper meaning of this thesis, it is useful to contextualize it within two partly independent medieval discussions. The first concerns the proper senses of the term scientia, ars, and philosophia; the second deals with the autonomy of philosophy and its place in the hierarchy of human knowledge.

As countless examples of medieval literature demonstrate, medieval thinkers treated scientia, ars, and philosophia as coextensive and even synonymous terms. As we have seen, Giles proceeds in this way, too. In De partibus philosophiae essentialibus he begins his analysis with the term scientia, then speaks about scientia sive ars, and, finally, adds philosophia-in each case having one and the same thing in mind.

So many terms describing the same thing probably seemed superfluous to medieval minds. As each of these three terms has associations not characteristic of the others, using the terms interchangeably would seem to risk confusion. Moreover, because these terms cover such a large and varied domain of objects, the introduction of some semantic specifications was necessary. Thus, medieval thinkers came to reflect on the proper meaning and peculiarities of scientia, ars, and philosophia. The most obvious result of this reflection was a new definition of art distinguishing it from science. We can find a typical argument in favor of the distinction in Kilwardby's De ortu scientiarum. He says there that the terms scientia and ars are not coextensive or synonymous because "science" involves speculation and "art" has as its effect a material thing. Hence, the term ars is to be applied only to mechanical science. As such, we should not use it to name metaphysics or any speculative science. ${ }^{43}$ We find similar reasoning in Thomas Aquinas's Super Boethium De Trinitate. ${ }^{4}$ According to Thomas, the term ars connotes necessarily, besides cognition, a product of work. Therefore, the possibility of the application of the term ars to philosophy is excluded. A conclusion following tacitly from Kilwardby's and Aquinas's lines of thought is that it is no longer possible to define philosophy as a liberal science, a conclusion wholly undermining the early medieval vision of science and philosophy. Although Giles does not oppose ars and scientia, I have included the distinction in my analysis because it shows the importance and the dimensions of the problem.

Another testimony to the reconstruction of the terminology pertaining to the system of sciences concerns the term scientia. Reflecting on the differences between practical and speculative science, Kilwardby concludes that the term scientia can be applied only to speculative sciences because only in them do proofs and arguments lead to general knowledge. So the term scientia must have only an analogical sense when applied to ethics and to other practical sciences. 45

43. Robert Kilwardby, De ortu scientiarum, XLV:416.

44. Thomas de Aquino, Super Boethium De Trinitate, II, 5, 1, ad 3.

45. Robert Kilwardby, De ortu scientiarum, XLI:380-81. 
In this context, texts from Aquinas's Super Boethium De Trinitate are even more interesting. Thomas argues that logic does not belong to the speculative sciences because, unlike logic, they are autothelic. Thomas expresses his views in a phrase that parallels Giles's formula; he says that logic is not contained in philosophy as a principal part. ${ }^{46}$

Finally, Kilwardby and Aquinas as well as Giles tend to differentiate the whole construction of the system of sciences by distinguishing a science par excellence or the essential part of science or philosophy, namely, metaphysics. In a certain sense this procedure is analogous to Aristotle's separating first philosophy from philosophy in general. They argue that the Aristotelian ideal of science can be satisfied only by philosophy and, more specifically, by metaphysics. This conception in some way transposes the juxtaposition of metaphysics and mechanics popular among medieval thinkers. For instance, in his Metaphysicales quaestiones, Giles presents metaphysics as liberal and theoretical in opposition to the mechanical sciences, which are identified as ancillary and practical, or even utilitarian. ${ }^{47}$ Giles's Commentaries on the Physics and Sophistical Refutations together with De partibus philosophiae essentialibus are succesive stages in the same process of differentiating the sciences. In his Quaestiones Giles sketches the general opposition, and in De partibus philosophiae essentialibus he builds groups of sciences around these contrasted branches of knowledge, that is, authentic philosophy around metaphysics and practical sciences around mechanics.

A second discussion affecting Giles's views on the nature of philosophy has to do with the problem of its place and value in human life. The period before Giles wrote De partibus philosophiae essentialibus was marked by the influence of another Aristotelian idea concerning the nature of philosophy. In addition to being the summit of human cognition, philosophy constituted an ultimate purpose of humanity and offered to human beings the sole felicity available to them. ${ }^{48}$ The best known formulation of this idea is

46. Thomas de Aquino, Super Boethium De Trintate, II, 5, 1, ad 2: "logica non continetur sub speculativa philosophia quasi principalis pars, sed sicut quidam reductum ad philosophiam speculativam". See also n. 14 concerning Albert the Great.

47. Aegidius Romanus, Metaphysicales quaestiones aureae (Venetiis, 1552), Apud Octavianum Scotum, I, Qu. 21 Utrum artes mechanicae sint meliores speculativis, f. 10v and Qu. 25 Utrum metaphysica sit libera vel serva, $\mathrm{f}$. 12r-12v.

48. Giles is aware of the problem of the felicity offered by philosophy and tries to solve it in a careful manner in his Metaphysicales quaestiones. He says that the felicity proposed by metaphysics is entirely different from that offered by theology. The theological felicity is supreme and cannot be treated by the metaphysician: "Felicitas est duplex, est enim quaedam felicitas, quae summe et simpliciter est felicitas, sicut illa, quam boni expectant in futuro post praesentem vitam, et de ista non intendimus ad praesens nec de ista loquitur Philosophus. Alia est felicitas, quae summe et simpliciter non est felicitas, et est illa, quae ex puris naturalibus acquiri potest, et ista est possiblis in praesenti vita et de hoc loquitur Philosophus et nos loqui intendimus" (see I, Qu. 1 Utrum metaphysica sit finis vel beatitudo hominis, f. 1ra). 
Boethius of Dacia's in his De summo bono sive de vita philosophi. Because Boethius's text has already received a great deal of attention, I shall present a brief review of some motifs discernible in two other texts illustrative of the widespread Boethian conception of philosophy, Albericus of Reims's Philosophia and John of Dacia's De divisione scientiae. These two texts belong to the series of general introductions to philosophy that came into existence in the milieu of the faculty of arts at the University of Paris. ${ }^{49}$

At the beginning of his Philosophia Albericus gives remarkable testimony of the reverence towards philosophy common in this milieu. He begins by calling philosophy the most splendid gift of God's generosity; continues by asserting that, according to Averroes, it is a realization of the perfection proper to human nature; and concludes by saying that it is the best way to the supreme good, namely, God Himself. 50

The same Boethian lofty evaluation of philosophy is part of the definitions of philosophy, mostly of ancient provenance, collected by John of Dacia. The most striking of these states that thanks to philosophy, human beings can become perfect, good, and even a god, according to the proposition from De consolatione that many are able to be gods by participation. Therefore, thanks to philosophy, human beings can not only realize their natural end, but also achieve something supranatural, namely, the divinization of the human essence. 51

In harmony with this high estimation of the role and function of philosophy, since it is the highest principle for human life, is the extension of philosophy's domain. According to Albericus the term "philosophy" is coextensive with sapientia and scientia. John of Dacia adds to this list ars, disciplina, doctrina, methodus, and facultas. In this way, philosophy is taken to be the sum of knowledge, as having everything as its object. Both authors maintain that these terms differ only conceptually. ${ }^{52}$

49. A more exhaustive list of texts of this kind has been offered by P. Gauthier in his "Notes sur Siger de Brabant. II. Siger en 1271-1275. Aubry de Reims et la scission des Normands," Revue des Sciences théologiques et philosophiques 68 (1984): pp. 3-28. See also p. 6. His presentation is not limited only to pure enumeration, but he also shows the mutual affiliations and similarities between these texts, which enables one to treat them as belonging to the same genre and manifesting more or less the same tradition.

50. Aubricus Remensis, Philosophia, published as an appendix to Gauthier's article (n. 49 above) in Revue des Sciences théologiques et philosophiques 68 (1984): pp. 29-49. See v. 5-44.

51. Johannes de Dacia, Divisio scientiae (in Johannes de Dacia, Opera, ed. A. Otto [Hauniae, 1955], p. 7, 1-3, Corpus Philosophorum Danicorum Medii Aevi, t. I): "Per philosophicam autem disciplinam perficitur homo et fit (bonus, immo deus, secundum quod dicit Boethius: natura deus est unus, participatione autem bonitatis plures."

52. See Aubricus Remensis, Philosophia, v. 265-79 and Johannes de Dacia, Divisio scientiae, p. 5, 12-26. The identification of the designates of the terms "philosophy," "science," "art," "discipline," and "doctrine" produces a kind of paradox. On the one hand, John of Dacia and Albericus of Reims emphasize one aspect 
Giles of Rome is conscious of the fact that the implications of this vision of philosophy are incompatible with the Christian worldview. Therefore, the emphasis he puts on the theoretical character of philosophy can be viewed as a guard against its practical pretensions. Indeed, Giles is aware of the practical function of metaphysics. To practice metaphysics means to contemplate, and this is the highest activity possible for human beings in this terrestrial existence. Philosophy's main purpose, however, is not this activity but pure cognition. Moreover, the practice of philosophy is placed under that of theology. In practical terms, theology has dominion over philosophy for two reasons. First, unlike metaphysics, it is a practical rather than a theoretical science. Second, the end that theology considers and to which it leads is supreme, namely, eternal glory.

In sum, the central thesis of Giles's De partibus philosophiae essentialibus - that only the speculative sciences consitute the essential parts of philosophy-contrasts philosophy with the mechanical sciences, on the one hand, and with theology, on the other. The whole structure of the human science consists in these three realms. Although they aim at different ends-philosophy at the aquisition of purely theoretical cognition, theology at salvation, and mechanics at the transformation of the external world-they are related to each other. We may sketch their mutual relations in a triangle:

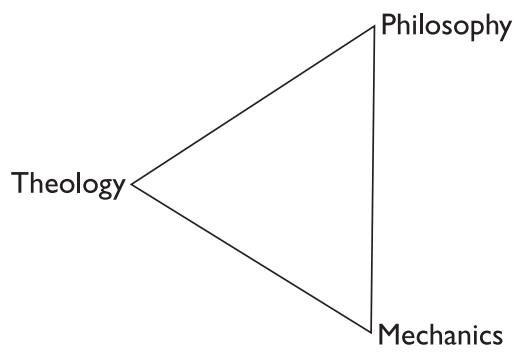

The triangle's vertices show the groups of sciences, while its sides depict their relations. Each vertex is opposed to the others and is allied separately with any one of them against the third one. For instance, philosophy as theoretical is opposed to theology and mechanics as practical. But philosophy is also united with mechanics, because both are effects of the activity of natural reason, in contrast to theology, which derives from divine inspiration. Philosophy, however, like theology, has as its object immaterial things, while, of course, mechanics deals with the material world.

of the Aristotelian theory of philosophy and, on the other hand, they present a system of sciences that is more similar-because of their acceptance of the division of arts into liberal and mechanical-to those of the twelfth century, which are less Aristotelian than Kilwardby's and Giles's. 


\section{APPENDIX}

Domini Aegidii de Roma archiepiscopi Bituricensis De partibus philosophiae essentialibus ac aliarum scientiarum differentia et distinctione tractatus ${ }^{1}$

Duae sunt causae entium: intellectus et natura etc., ut vult Philosophus II Physicorum. ${ }^{2}$ Ex his autem duabus causis per se, videlicet ex natura et intellectu, sumunt originem duae causae per accidens, casus scilicet et fortuna. Nam ex intellectu sumit originem fortuna, quia, ut in eodem II habetur, "fortuna est in agentibus a proposito propter aliquid." 3 Ex natura vero sumit originem casus, quia circa causas naturales contingit esse casus, sed non fortuna.

Cum igitur in omnibus considerandum sit, quod est per se, et dimittendum, quod est per accidens, ut vult Philosophus V Ethicorum, ${ }^{4}$ si distinctionem scientiarum sumere volemus, non accipiemus eam ex fortuna et casu, quae sunt causae per accidens, sed ex natura et intellectu, quae sunt causae per se. Intellectus autem in causando distinguitur a natura. Et, ut dicimus, quod aliud est causatum a natura, aliud ab intellectu, oportet accipere intellectum non pro intellectu divino vel intellectu substantiarum separatarum, sed pro intellectu humano.

20 Consentiunt enim philosophi, quod causatur a natura, causari ab intellecto divino et ab intellectu substantiarum separatarum. Aiunt enim, quod opus naturae est opus intelligentiae. Unde Commentator XII Metaphysicae ait, quod "natura non agit, nisi rememorata ab intelligentia vel a superioribus causis," ${ }^{5}$ quae sunt

25 intelligentiae. Sicut ergo pars, quia comprehenditur in toto, non proprie distinguitur contra totum, sic actio naturae quia comprehenditur in actione divina et substantiarum separatarum, natura, ut est causa entium, non distinguitur contra intellectum divinum vel contra substantias separatas, sicut nec organum et instrumentum, ut est

1. This text is based on the German incunabulum, Tres tractatus domini Aegidii de Roma, Lipsiae circa 1490, containing De partibus philosophiae essentialibus, De differentia rhetoricae, ethicae et politicae and De gradibus formarum accidentalium. Some necessary corrections are marked by [ . . . ].

2. Aristoteles, Physica, II, 1-2, 192b8-19b15.

3. Aristoteles, Physica, II, 5, 197a5-8.

4. Aristoteles, Ethica nicomachea, V, 8, 1135a16sequ.

5. Averroes, In Metaphysicam, XII, comm. 18, (Apud lunctas, t. VIII, f. 305DE). 
activum et causativum, dividitur contra principale agens. Nam omnis actio organi est actio principalis agentis. Natura autem est organum intelligentiarum et Dei. Nam, ut ait Commentator XII Metaphysicae, "quae hic inferius aguntur, habent proprias mensuras ab intelligentiis et ab arte divina intellectuali,"6 sub qua fiunt artes plures. Sub arte enim divina sunt omnes intellectus substantiarum separatarum et omnes artes earum. Cum ergo ait Philosophus duas esse causas entium naturam et intellectum, oportet ibi accipere intellectum pro intellectu humano. Hoc enim modo accipiendo intellectum, natura est alia causa ab intellectu et actio naturae non est actio intellectus nostri, licet sit actio intellectus divini. Est enim natura medium inter intellectum divinum et humanum. Nam res naturales sunt mediae inter scientiam Dei et scientiam nostram. Causantur enim huiusmodi res a scientia Dei, sed sunt causae scientiae nostrae. $<$ fol. a2r $>$ Unde Commentator super capitulo Sententia patrum praecedens omnia dans differentiam inter scientiam divinam et nostram ait, quod "scientia Dei causat res, scientia nostra causatur a rebus."7 Quod non est intelligendum de rebus quibuslibet. Nam agibilia et artificialia causantur a scientia nostra. Possumus autem dicere, quod sicut naturalia sunt media inter intellectum divinum et nostrum, sic intellectus

50 noster est medius inter naturalia et artificialia. Nam sicut naturalia causantur a scientia Dei et causant scientiam nostram, sic scientia, quae est in intellectu nostro, causatur a naturalibus et causat artificialia.

Prima ergo divisione sic dividi possunt entia: quaedam sunt 55 causae scientiae nostrae, quaedam vero sunt causata a nobis et ab intellectu nostro. Ea vero, quae ab intellectu nostro causantur, in triplici genere esse videntur, quia quaedam sunt intentionalia, ut intentiones, quae sumunt originem ex actionibus rationis; quaedam vero dicuntur esse realia; et haec distinguuntur, quia quaedam sunt 60 factibilia, quaedam agibilia. Factibilia autem dicuntur, ex quibus resultat aliquod factum vel aliquid in effectu, cuiusmodi sunt opera artium mechanicarum, ut ex arte fabrili resultat cultellus, ex domificativa domus. Agibilia vero sunt opera deservientia nobis ad vitam perfectam sive ad vitam virtuosam et felicem, ex quibus non resultat aliquod factum, cuiusmodi sunt opera prudentiae et aliarum virtutum. Unde Philosophus in Ethicis dans differentiam inter prudentiam et artem ait, quod "prudentia est recta ratio agibilium, ars vero est recta ratio factibilium." 8 Bene ergo dictum est in triplici genere esse ea, quae ab intellectu nostro causantur, quia quaedam sunt intentionalia, quaedam agibilia, quaedam factibilia. Accipiendo ens

6. Averroes, In Metaphysicam, XII, comm. 18, (Apud lunctas, t. VIII, f. 305D).

7. Averroes, In Metaphysicam, XII, comm. 51 (Apud lunctas, t. VIII, f. 337B).

8. Aristoteles, Ethica nicomachea, VI, 5, 1140b2-31. 
large, prout ipsae intentiones sunt quaedam entia, dicere possumus entia esse in quadruplici gradu, quia quaedam sunt realia causantia scientiam nostram, quaedam intentionalia, quaedam agibilia, quaedam factibilia.

75 Dimissa ergo grammatica, quae in multis ad placitum esse videtur, dici potest, quod secundum haec quattuor genera entium sunt quattuor genera scientiarum. Nam scientiarum sive artium quaedam sunt speculativae reales, quaedam rationales, quaedam morales, quaedam mechanicae. De entibus igitur realibus causan80 tibus scientiam nostram sunt scientiae speculativae. De intentionalibus vero sunt scientiae rationales. De agibilibus vero sunt morales. De factibilibus sunt artes mechanicae.

Harum autem artium solae speculativae essentiales partes philosophiae esse dicuntur. Nam philosophia est propter inquisitionem

85 veritatis. Veritas autem maxime consurgit ex his, quae sunt per se et principale obiectum intellectus. Ad hoc igitur, quod aliqua ars sit principalis pars et essentialis philosophiae, duo requiruntur. Primo, quod in ea finaliter intendatur veritas. Secundo, quod sit de eis, quae sunt per se et principale obiectum intellectus. Artes ergo morales et

90 mechanicae essentialis pars philosophiae esse non possunt. Nam cum huiusmodi $<$ fol. a2v $>$ artes sint practicae, in eis non principaliter intenditur veritas, sed opus; quia, ut scribitur II Metaphysicae, "finis speculativae est veritas, practicae vero opus."9 In moralibus enim intenditur pricipaliter non veritas, sed opus agibile, in

95 mechanicis vero opus factibile, propter quod talia essentialiter ad philosophiam pertinere non possunt. Artes autem rationales etiam essentialis pars philosophiae esse non possunt. Nam etsi in eis principaliter intenditur veritas, quia dialectica, quae rationalis est, ut a multis conceditur, indagativa est veritatis, non tamen tales artes 100 essentialiter ad philosophiam pertinent, quia non sunt de his, quae sunt principale obiectum intellectus. Intentiones enim, de quibus sunt artes rationales, non sunt principale obiectum intellectus, sed res.

Solae igitur scientiae speculativae, quae sunt de rebus, cuius105 modi sunt physica, mathematica et divina, essentialiter ad philosophiam pertinent. Bene igitur dictum est, quod scribitur VI Metaphysicae, quod "triplex est modus essentialis philosophiae: physicus, mathematicus et divinus."10 Ex hoc ergo patere potest, quomodo distingui habent scientiae speculativae. Nam si huiusmodi 110 scientiae sunt de his, quae sunt per se et principale obiectum intellectus, et cum per se et principale obiectum intellectus sit quid abstractum, secundum diversum modum abstractionis oportet ac-

9. Aristoteles, Metaphysica, II, 1, 993b20-21.

10. Aristoteles, Metaphysica, VI, 1, 1026a18-19, translatio Michaelis Scoti. 
cipere diversitatem talium scientiarum. Omnis enim scientia speculativa abstrahit, sed non omnis aequaliter abstrahit, immo est ibi triplex gradus abstractionis, secundum quem triplicem gradum accipiuntur praedicta tria genera scientiarum. Priumus enim gradus abstractionis est, ut fiat abstractio ab hac materia sensibili et ab illa, sed non a materia sensibili simpliciter, et est modus abstractionis physicus. Hoc ergo modo accipitur scientia naturalis. Secundus gra120 dus abstractionis est, ut fiat abstractio a materia sensibili simpliciter, sed non a materia intelligibili, et sic accipitur scientia mathematica. Tertio modo potest sumi abstractio ab omni materia sensibili et intelligibili, et hic est modus metaphysicus et divinus. Metaphysica enim est de ipsis intelligentiis, de quibus dicitur VIII Metaphysicae, quod sunt entes praeter omnem "materiam sensibilem et intelligibilem."11 Omnis ergo scientia speculativa vel est de abstractis secundum esse et definitionem, et sic est metaphysica, vel de abstractis secundum definitionem, sed non secundum esse, et sic est mathematica, vel nec de abstractis secundum definitionem nec secundum esse, et sic est naturalis sive physica. Naturalis autem scientia et metaphysica non distinguuntur in plures scientias, sed mathematica plures scientias sub se habet. Nam quaedam mathematica est de quantitate secundum se et absolute, quaedam vero de quantitate contracta et relata ad aliud. De quantitate autem secundum se est duplex scientia, secundum quod duplex est genus quantitatis. Nam de quantitate continua est geometria, de discreta est arithmetica. De quantitate autem $<$ fol. a3r $>$ contracta et relata ad aliud sunt plures, secundum quod pluribus modis talis relatio et talis contractio esse habet, ut de quantitate discreta relata ad sonum est musica, de quantitate vero relata ad distantias stellarum et ad motus supercaelestium orbium est astronomia. Propter quod geometria et arithmetica sunt scientiae principales et simpliciter. Astronomia vero et musica sunt scientiae ex suppositione et subalternatione. Sicut ergo secundum subalternationem, secundum quod quantitas continua vel discreta refertur ad aliud, accepta est astronomia et musica, sic accipi possunt plures aliae scientiae: ut ex relatione ad visum accipitur perspectiva, quae est de linea relata ad visum sive de linea visuali, ex relatione vero ad aedificia accipitur steriometria, quae est de mensura aedificiorum. Patet ergo, quomodo accipi habet distinctio speculativarum scientiarum tam principalium quam sublaternarum.

Distinctio autem mechanicarum sumitur ex distinctione et secundum diversitatem factibilium, quae ex talibus artibus resultant. Nam, ut dicebatur, ars mechanica est recta ratio factibilium. Oportet ergo [tales] ${ }^{12}$ differre, secundum quod factibilia distinguuntur.

11. Aristoteles, Metaphysica, VIII, 6, 1045a36.

12. [tales] correxi, in incunabulo "talia." 
155 Talium igitur artium alia erit fabrilis, alia dolativa, alia carpentaria, alia lanificativa, alia textoria, et sic de aliis, prout secundum eas diversa factibilia esse habent. Est enim inter has artes differentia, quia quaedam magis negotiatur circa materiam, quaedam autem magis circa formam, quaedam sunt magis dominativae et architec-

160 tonicae, quaedam vero sunt magis servientes et ancillae, ut navefactiva est architectonica respectu dolativae et textoria respectu lanificativae. Secundum ergo differentiam factibilium et secundum differentiam principalitatis et [ancillativitatis] ${ }^{13}$ distinctio mechanicarum artium sumi habet.

165 Morales autem scientiae, quae maxime sunt, ut boni fiamus (nam in talibus scire modicum utile est, operari vero multum), distingui habent secundum diversas communicationes et secundum differentiam bonitatum in communicationibus repertarum. Omnis enim communitas bonum aliquod coniecturat, ut dicitur I Politi170 corum. ${ }^{14}$ Secundum igitur triplicem communicationem sumitur triplex scientia moralis. Videmus enim unam communicationem et unum regnum, prout diversae potentiae animae ordinantur ad intellectum, ut irascibilis et concupiscibilis, quae sunt rationales per participationem, ordinantur ad idem, quod est rationale per essentiam.

175 Et talis communicatio sive tale regnum est in una persona singulari. Secunda communitas est, prout diversae personae ordinantur ad unum patremfamilias, ut uxor, filius, servus etc. ordinantur ad unum gubernatorem familiae. Et tale regimen est in una domo. Tertia communicatio est, prout ordinantur ad unum principem et ad

180 unum ducem. Et talis communicatio sive tale regnum est in civitate vel regno. Secundum ergo has tres communicationes, in quibus alia et alia ratio est bonitatis, accipitur ethica, oeconomica et $<$ fol. a3v $>$ politica, ut de regimine sui, prout per intellectum quis alias potentias animae regit, tractat ethica; de regimine vero familiae, prout pater-

185 familias gubernare habet uxorem, filios et servos, tractat oeconomica; de regimine vero civitatis et regni tractat politica.

Viso ergo, quomodo distinguuntur scientiae speculativae, artes mechanicae et morales, restat videre, quomodo distinguuntur sicentiae rationales. Huiusmodi autem scientiae, accipiendo large actus

190 rationis, rationales sunt, quia sunt de actibus rationis. Dico autem accipiendo large, quia, ut In Elenchis ${ }^{15}$ diffusius diximus, scientiae rationales non proprie sunt de actibus rationis, sed sunt de intentionibus formatis per huiusmodi actus. Inductio enim, exemplum et enthymema et syllogismus, de quibus sunt scientiae rationales, non

13. [ancillativitatis] correxi, in incunabulo "acillativae."

14. Aristoteles, Politica, I, 1, 1252a1-5.

15. Aegidius Romanus, In Aristotelis De sophisticis elenchis commentum, ed. Augustinus de Meschiatis (Venetiis, 1496-1497), f. 2sequ. 
195 proprie dicuntur actus rationis, sed magis dicimus esse intentiones formatas per huiusmodi actus rationis. Syllogismus enim et inductio non dicunt ipsum intelligere, sed dicunt aliquid formatum per intellectum. Accipiuntur ergo scientiae rationales, secundum quod tales intentiones diversificari habent. Sicut enim, quia bonum gentis est

200 divinius quam bonum unius, scientia, quae determinat de bono gentis, ut politica, est alia a scientia, quae determinat de bono unius, ut ab ethica, sic, quia syllogismus efficacius arguit quam enthymema et inductio quam exemplum, dialectica, quae principaliter est de syllogismo et inductione, est alia a rhetorica, quae est de enthyme205 mate et exemplo. Duae ergo sunt artes rationales: rhetorica et dialectica, quae differunt eo, quod una efficacius arguit quam alia. Unde in I Rhetoricorum dicitur, quod "rhetorica est assecutiva dialecticae", 16 ambae enim sunt de quibusdam communibus, ambae sunt de quibusdam intentionibus et de quibusdam actibus rationis, quae

210 nullius scientiae est considerare. Patet ergo, quomodo rhetorica differt a dialectica, nam rhetorica est assecutiva dialecticae et inferior ea et deficit ab ea et principaliter est de enthymemate et exemplo, quae deficiunt ab inductione et syllogismo.

Praetermissa ergo divisione rhetoricae, quia de ea non est 215 speculatio praesens, divisionem dialecticae videamus. Dictum est autem dialecticam non esse de actibus rationis, sed de intentionibus formatis per huiusmodi actus. Prout ergo intellectus aliud et aliud format, accipienda est alia et alia pars dialecticae. Tria enim facit intellectus intelligendo. Nam intellectus primo intelligit simplicia et 220 deinde intelligit composita. Vel intelligit ea simplici intuitu et in se ut principia, vel intelligit ea cum discursu et in ordine ad aliud ut conclusiones. Cum ergo intelligit simplicia, format definitionem, per quam definitionem formatam in mente significat res vel definitum sive nomen, iuxta illud IV Metaphysicae: 17 ratio, quam significat 225 nomen, est definitio. Prout vero intellectus intelligit composita simplici intuitu, $<$ fol. a4r $>$ format enuntiationem. Sed prout intelligit cum discursu, format rationem et syllogismum. Tota ergo dialectica vel est de termino incomplexo ut liber Praedicamentorum, vel de enuntiatione ut Perihermeneia, vel de syllogismo ut libri artis novae.

230 Liber autem Porphyrii et Sex principiorum, quae Aristoteles non edidit, non sunt essentiales partes logicae, sed sunt quaedam adminiculantia ad ipsam. Sicut enim intellectus tria format, videlicet definitionem, enuntiationem et syllogismum, sic oportet esse tres essentiales partes logicae: unam, quae determinat de termino incomplexo, qui significat definitionem in mente conceptam, et aliam,

16. Aristoteles, Rhetorica, I, 1, 1354a1, translatio Guillelmi Moerbeke.

17. Aristoteles, Metaphysica, IV, 7, 1012a23-24. 
quae determinat de enuntiatione, et aliam, quae determinat de syllogismo, cuiusmodi (ut dicebatur) est tota [ars.] ${ }^{18}$ nova.

Potest ergo accipi distinctio librorum artis novae, prout diversimode determinari habet de syllogismo: vel enim determinat de 240 syllogismo universaliter secundum se, sic est liber Priorum, vel ut habet esse contractum. Hoc erit dupliciter, quia haec contractio vel est per necessitatem materiae, vel per habitudinem localem. Si per necessitatem materiae, sic est liber Posteriorum, ubi tractatur de syllogismo demonstrativo, qui [est] ${ }^{19}$ ex veris et necessariis et causis 245 conclusionis. Si vero fit talis contractio per habitudinem localem, vel illae habitudines sunt congruae et probabiles, vel nec sunt congruae, nec probabiles, sed videntur esse congruae et probabiles. Primo modo est liber Topicorum, ubi determinatur de syllogismo sive elencho secundum se, qui fulciri habet per habitudines locales con250 gruas et probabiles. Secundo modo est liber Elenchorum, ubi determinatur de syllogismo sophistico et elencho non secundum se, sed ut obliquari habet per argumentationes sophisticas, quae argumentationes sophisticae fulciri habent per habitudines locales, quae nec sunt probabiles nec congruae, sed videntur esse congruae [et $]^{20}$ 255 probabiles.

Et haec sufficiant.

18. [ars] correxi, in incunabulo "pars."

19. [est] addidi.

20. [et] addidi. 